Klinichna khirurhiia. 2018 May;85(5):40-43.

DOI: $10.26779 / 2522-1396.2018 .05 .40$

УДК 615.33^616-001-036.8-037-056.43

\title{
Прогнозування перебігу загоєння ран у хворих з алергією на антибіотики
}

\author{
О. В. Стороженко, О. В. Лігоненко, Д. М. Іващенко, А. Б. Зубаха, \\ I. О. Чорна, I. А. Шумейко \\ Українська медична стоматологічна академія, м. Полтава
}

\section{Prognostication of the wounds healing course in patients, suffering allergy for antibiotics}

\author{
O. V. Storozhenko, O. V. Lihonenko, D. M. Ivashchenko, A. B. Zubakha, \\ I. O. Chorna, I. A. Shumeiko \\ Ukrainian Medical Stomatological Academy, Poltava
}

\begin{abstract}
Реферат
Мета. Розробити прогностичну модель перебігу загоєння ран у хворих з алергією на антибіотики.

Матеріали і методи. Для побудови прогностичної моделі використані методи бінарного логістичного регресійного аналізу. Дієвість запропонованої прогностичної моделі перевіряли на новій вибірці хворих із гнійними ранами м'яких тканин та алергічними реакціями на антибіотики

Результати. Статистично значущий вплив на перебіг ускладненого загоєння ран (хронізація рани) мають: порушення кровообігу в ділянці рани - 11,3\%, ступінь мікробного забруднення рани більше 2 × $10^{5}$ КУО/мл - $24 \%$, наявність у хворого цукрового діабету (ЦД) - 24\%, деструктивно-запальний тип цитограми - 36,2\%. Побудована прогностична модель дала змогу прогнозувати ускладнений перебіг загоєння ран у хворих з алергією на антибіотики. Рівень статистичної значущості для прогностичної моделі в цілому - p=0,002.

Висновки. Розроблений прогностичний алгоритм доцільно використовувати як дієвий спосіб прогнозу перебігу загоєння ран у хворих з алергією на антибіотики.

Ключові слова: гнійні рани; алергія на антибіотики; прогнозування загоєння ран.

Abstract

Objective. To elaborate a prognostication model for the wounds healing course in patients, suffering allergy for antibiotics. Materials and methods. The methods of binary logistic regression analysis were used for elaboration of the prognosis model. Efficacy of the prognosis model proposed was checked on a new contingent of patients, suffering purulent wounds of soft tissues and allergic reactions for antibiotics.

Results. Statistically significant impact on complicated healing of the wounds (the wound chronization) had following factors the blood circulation disorder in the wound site $-11.3 \%$, a microbial contamination degree more than $2 \times 10^{5} \mathrm{CFU} / \mathrm{ml}-24 \%$, presence of diabetes mellitus in patient $-24 \%$, destructive-inflammatory type of cytogram $-36.2 \%$. The prognosis model elaborated have permitted to prognosticate a complicated course for the wounds healing in patients, suffering allergy for antibiotics. In total, the level of statistical significance for the prognosis model constitutes $\mathrm{p}=0.002$.

Conclusion. The prognostic algorithm elaborated is expedient to apply as efficient method for prognostication of the wounds healing course in patients, suffering allergy for antibiotics.

Keywords: purulent wounds; allergy on antibiotics; prognosis for the wounds healing.
\end{abstract}

Проблема прогнозування ускладненого загоєння ран у пацієнтів з алергією на антибіотики недостатньо розроблена, особливо щодо можливості прогнозування розвитку хронічного запалення в ділянці рани та затяжного перебігу ранового процесу $[1,2]$. Традиційний підхід до вирішення проблеми прогнозування перебігу захворювання, у тому числі й загоєння ран, полягає в побудові автоматизованих систем прогнозування на підставі нейромережевого або регресійного аналізу [1, 3 - 7].

Мета дослідження: розробити прогностичну модель перебігу загоєння ран у хворих з алергією на антибіотики.

\section{Матеріали і методи дослідження}

Побудову прогностичної моделі розпочали з визначення найбільш важливих чинників, які можна розглядати як потенційні прогностичні чинники (предиктори) перебігу загоєння ран у хворих з алергією на антибіотики. Таких чинників ми визначили 21 (в дужках наведені їх можливі значення): вік (інтервальна змінна); стать (чоловіки, жінки); температура тіла (інтервальна змінна); рівень у крові лейкоцитів (інтервальна змінна), лімфоцитів (інтервальна змінна), еозинофілів (інтервальна змінна); рівень у сироватці крові фібриногену (інтервальна змінна), загального білка (інтервальна змінна), С-реактивного білка (СРБ) (інтервальна змінна); лейкоцитарний індекс інтоксикації (ЛІІ) (інтервальна змінна), індекс маси тіла (IMT) (інтервальна змінна); мікробне забруднення рани (інтервальна змінна); тип цитограми (некротичний, деструктивно-запальний, запальний, запально-регенеративний, регенеративно-запальний, регенеративний); наявність у хво- 
рого Цд (так, ні), хронічної артеріальної недостатності (ХАН) (так, ні), хронічної венозної недостатності (ХВН) (так, ні), ішемічної хвороби серця (IXC) (так, ні), полінейропатії (ПНП) (так, ні), іншої супутньої патології (так, ні); локалізація рани (голова та шия, верхні кінцівки, нижні кінцівки, промежина, тулуб); порушення кровообігу в ділянці рани (так, ні).

Брали до уваги ті значення інтервальних змінних, які визначали на 3-тю - 5-ту добу загоєння ран, оскільки цей термін вважають важливим у завершенні гострого запалення та переході до повноцінної регенерації, а відхилення від цієї послідовності призводить до порушення загоєння ран.

Далі визначили, які з перелічених чинників (незалежних змінних) і в якій мірі можуть впливати на перебіг загоєння ран (залежну змінну). Для цього проаналізували історії хвороб 58 хворих із запально-гнійними ураженнями м'яких тканин, які мали алергічні реакції на антибіотики,

\section{Таблиця 1. Статистична значущість потенційних прогностичних чинників перебігу загоєння ран}

Прогностичні чинники (предиктори)

Вік, роки $(\bar{x} \pm m)$

Стать

чоловіки

жінки

Температура тіла, ${ }^{\circ} \mathrm{C}(\overline{\mathrm{x}} \pm \mathrm{m})$

Лейкоцити, $\times 10^{y}$ в 1 л $(\bar{x} \pm m)$

Лімфоцити, \% ( $\bar{x} \pm m)$

Еозинофіли, \% ( $\bar{x} \pm m)$

Фібриноген, $r / л ~(\bar{x} \pm m)$

Загальний білок, $r / л(\bar{x} \pm m)$

СРБ

-
+
++
+++
गII, у. о. $(\overline{\mathrm{x}} \pm \mathrm{m})$

\begin{tabular}{ccc}
\multicolumn{2}{c}{ Перебіг загоєння ран } & \\
ускладнений & неускладнений & 0,031 \\
$62,3 \pm 7,4$ & $44,5 \pm 6,1$ & \\
\cline { 1 - 2 } 10 & 26 & 0,49 \\
8 & 14 & 0,181 \\
$37,5 \pm 0,2$ & $37,3 \pm 0,3$ & 0,468 \\
$9,7 \pm 1,2$ & $9,5 \pm 2,2$ & 0,632 \\
$19,25 \pm 3,2$ & $21,12 \pm 2,9$ & 0,042 \\
$7,3 \pm 1,2$ & $5,1 \pm 0,7$ & 0,318 \\
$6,82 \pm 2,1$ & $4,46 \pm 1,2$ & 0,045
\end{tabular}

\begin{tabular}{cc|c}
2 & 12 \\
3 & 13 & \\
7 & 10 & 0,045 \\
6 & 5 & \\
\hline $2 \pm 0,4$ & $1,8 \pm 0,3$ & 0,028
\end{tabular}

Локалізація рани голова та шия

верхні кінцівки

нижні кінцівки

тулуб

промежина

$2,2 \pm 0,4$

$1,8 \pm 0,3$

0,028

Порушення кровообігу в рані

так 11

Hi

IMT, y.o. $(\overline{\mathrm{x}} \pm \mathrm{m})$

Мікробне забруднення рани, $\times 10^{5}$ КУО/мл $(\bar{x} \pm m)$

Тип цитограми

деструктивно-запальний
запальний

IXC

так

$\mathrm{Hi}$

ЦД

так

ХАН

так

Hi

ПНП

так

$\mathrm{Hi}$

$\mathrm{XBH}$

так

Hi

Інша супутня патологія

так

Hi

7
6
1
3
1

$19,7 \pm 0,7$

$2,5 \pm 0,3$

$\begin{array}{cc}12 & 15 \\ 6 & 25\end{array}$

5

13

8

4

14

5

13

3

15

7

11

8

32

7

33

6

34

4

5

27

\section{7}

9

12
7

12

0,025

$21,2 \pm 0,8$

$1,4 \pm 0,3$

0,317

$<0,001$

\section{5}

0,510

0,03

0,5

36

0,084

35

0,670

13

0,640 


\begin{tabular}{|c|c|c|}
\hline Таблиця 2. & \multicolumn{2}{|c|}{$\begin{array}{l}\text { Статистично значущі прогностичні } \\
\text { чинники перебігу загоєння ран } \\
\text { після категоризації }\end{array}$} \\
\hline $\begin{array}{l}\text { Прогностичні } \\
\text { чинники } \\
\text { (предиктори) }\end{array}$ & Категорія & Код \\
\hline \multirow{2}{*}{ Вік, роки } & більше 55 & 1,0 \\
\hline & 55 і менше & 0,0 \\
\hline \multirow{2}{*}{$\begin{array}{l}\text { Кількість } \\
\text { еозинофілів, \% }\end{array}$} & більше 5 & 1,0 \\
\hline & 5 і менше & 0,0 \\
\hline \multirow{2}{*}{ Рівень СРБ } & більше ++ & 1,0 \\
\hline & ++ і менше & 0,0 \\
\hline \multirow{2}{*}{ ЛII, у. о. } & більше 1,8 & 1,0 \\
\hline & 1,8 і менше & 0,0 \\
\hline \multirow{2}{*}{$\begin{array}{l}\text { Рівень } \\
\text { фібриногену, г/л }\end{array}$} & більше 4,44 & 1,0 \\
\hline & 4,44 і менше & 0,0 \\
\hline \multirow{2}{*}{ Тип цитограми } & деструктивно-запальний & 1,0 \\
\hline & запальний & 0,0 \\
\hline \multirow{2}{*}{$\begin{array}{l}\text { Мікробне } \\
\text { забруднення, } \\
\text { КУО/мл }\end{array}$} & більше $1,5 \times 10^{5}$ & 1,0 \\
\hline & $1,5 \times 10^{5}$ і менше & 0,0 \\
\hline \multirow{2}{*}{ цД } & так & 1,0 \\
\hline & $\mathrm{Hi}$ & 0,0 \\
\hline \multirow{2}{*}{ Локалізація рани } & нижні кінцівки та промежина & 1,0 \\
\hline & інші ділянки тіла & 0,0 \\
\hline $\begin{array}{l}\text { Порушення } \\
\text { кровообігу в рані }\end{array}$ & так & 1,0 \\
\hline
\end{tabular}

та з'ясували, що у 18 (27,6\%) з них перебіг ранового процесу характеризувався ознаками хронічного запалення.

Усіх хворих розподілили на дві групи, виходячи із значень залежної змінної (перебігу загоєння ран), тобто до 1-ї групи увійшли 18 хворих з ускладненим, до 2-ї - 40 хворих $з$ неускладненим загоєнням ран. Під ускладненим загоєнням ран розуміли затяжний (більше 3 тиж) перебіг ранового процесу з млявим ростом грануляцій та уповільненою епітелізацією.

\section{Результати}

За допомогою бінарного логістичного регресійного аналізу встановили рівень кореляції залежної змінної від незалежних, тобто визначили рівень статистичної значущості залежності ускладненого та неускладненого загоєння ран від визначених прогностичних чинників. Виявилось, що з 21 визначеного прогностичного чинника лише 10 мають статистично значущий вплив на перебіг загоєння ран, а саме: вік, рівень еозинофілів у крові, piвень фібриногену, СРБ у сироватці крові, ЛІІ, мікробне забруднення рани, тип цитограми, наявність Цд, локалізація рани, порушення кровообігу в рані (табл. 1). Ці чинники були включені для побудови регресійної моделі перебігу загоєння ран.

Як регресійну модель вибрали категоріальну регресію (CATREG), яка є регресією оптимального шкалювання (Regression with Optimal Scaling), у зв'язку з тим, що, окрім стандартизованих коефіцієнтів регресії, внаслідок аналізу обчислюються так звані коефіцієнти відносної важливості Пратта (Pratt's importance), тобто оцифровуються категоріальні незалежні змінні (прогностичні чинни-

\begin{tabular}{|l|ccc|}
\hline Таблиця 3. & \multicolumn{3}{|c|}{ Результат регресійного аналізу } \\
3 оптимальним шкалюванням
\end{tabular}

\section{Таблиця 4. Результат бінарного логістичного регресійного аналізу}

\begin{tabular}{lc} 
Прогностичні чинники (предиктори) & Коефіцієнти регресії (b) \\
\hline Вік & $+0,15$ \\
Рівень фібриногену & $-9,23$ \\
\hline Наявність ЦД & $+31,51$ \\
Локалізація рани & +21 \\
\hline Тип цитограми & $+0,16$ \\
Рівень еозинофілів & $+0,68$ \\
Рівень СРБ & $+2,55$ \\
Мікробне забруднення рани & $+30,46$ \\
Порушення кровообігу в рані & $+9,15$ \\
ЛІІ & $-19,96$
\end{tabular}

ки) та визначаються найбільш вагомі з них. Оскільки дана регресійна модель оперує лише категоріальними змінними, всі включені інтервальні та порядкові прогностичні чинники (предиктори) були категоризовані з присвоєнням певній категорії значень відповідного коду (табл. 2).

Обчислені коефіцієнти регресії та коефіцієнти важливості прогностичних чинників наведені в табл. 3. Знак «+»перед коефіцієнтом регресії вказує на кореляцію між залежною змінною і предиктором, закодованим як 1,0, a знак «-» - на кореляцію між залежною змінною і предиктором, закодованим як 0,0. Рівень статистичної значущості для моделі в цілому $-\mathrm{p}=0,032$.

Абсолютні значення коефіцієнтів важливості пропорційні коефіцієнтам регресії, а отже, пропорційні ступеню впливу кожного предиктора на значення залежної змінної (перебігу загоєння ран).

Тому коефіцієнти важливості вибрані нами як вагомі значення впливу прогностичних чинників на перебіг загоєння ран. Для цього для кожного прогностичного чинника (предиктора) вираховували його вагомий бал шляхом множення абсолютного значення відповідного коефіцієнта важливості на 100.

Як видно з табл. 3, найбільш вагомий вплив на перебіг загоєння ран мають: порушення кровообігу в ділянці рани - 11,3\%, ступінь мікробного забруднення рани (біль- 
ше $2 \times 10^{5}$ КУО/мл) - 24\%, наявність у хворого ЦД - 24\% та тип цитограми - 36,2\%.

За допомогою методів бінарного логістичного регресійного аналізу ми побудували прогностичну модель, яка уможливлює з певною вірогідністю прогнозувати ускладнений перебіг загоєння ран в залежності від показників означених прогностичних чинників у конкретного хворого з алергією на антибіотики. Рівень статистичної значущості для моделі в цілому - $\mathrm{p}=0,002$.

Вірогідність прогнозу ускладненого перебігу загоєння ран вираховували за формулою:

$\mathrm{P}=1 /\left(1+\mathrm{e}^{-\mathrm{Z}}\right)$, де:

$\mathrm{z}=\left(\mathrm{b}_{1} \times \mathrm{x}_{1}\right)+\left(\mathrm{b}_{2} \times \mathrm{x}_{2}\right)+\ldots .+\left(\mathrm{b}_{\mathrm{n}} \times \mathrm{x}_{\mathrm{n}}\right)+\alpha$,

$\mathrm{x}-$ значення незалежних змінних (прогностичних чинників),

b - коефіцієнти регресії незалежних змінних (прогностичних чинників), обчислені програмою (табл.4),

$\alpha$ - обчислена програмою константа, яка становила $-23,43$

е - математична константа, яка дорівнює 2,718.

Якщо значення Р було менше 0,05, вважали, що подія не настане.

Для спрощення проведення наведених математичних розрахунків ми побудували за допомогою компілятора Microsoft Visual C++ комп'ютерну програму, в інтерфейс якої лише вводили значення прогностичних чинників конкретного хворого, і вона автоматично видавала результати прогнозу (вірогідності ускладненого перебігу загоєння ран).

Дієвість запропонованої прогностичної моделі перевіряли на новій вибірці хворих із гнійними ранами м'яких тканин та алергічними реакціями на антибіотики. Перебіг загоєння ран на 68\% збігався з прогнозованим.

\section{Обговорення}

Проведене дослідження показало, що статистично значущий вплив на перебіг загоєння ран у хворих з алергією на антибіотики мають: вік, рівень еозинофілів у крові, фібриногену та СРБ у сироватці крові, ЛІІ, мікробне забруднення рани, тип цитограми, наявність Цд, локалізація рани, порушення кровообігу в рані. Найбільш вагомий вплив на перебіг ускладненого загоєння ран (хронізація рани) мають: порушення кровообігу в ділянці рани - 11,3\%, ступінь мікробного забруднення рани (більше $2 \times 10^{5}$ КУО/ мл) - 24\%, наявність у хворого ЦД - 24\% та деструктивно-запальний тип цитограми - 36,2\%. Розроблений алгоритм прогнозування перебігу загоєння ран дає змогу оптимізувати лікувальну тактику у хворих з гнійними ранами м'яких тканин та алергією на антибіотики.

\section{Висновки}

Розроблений прогностичний алгоритм доцільно використовувати як дієвий спосіб прогнозу перебігу загоєння ран під час лікування гнійних ран м'яких тканин у хворих з алергією на антибіотики.

\section{References}

1. Ivashchenko DM, Lihonenko OV, Digtyar II. Use of Bacteriophages in the Treatment of Infected Wounds in Patients who have Allergy to Antibiotics. Surgical Chronicles. 2016 Dec;21(4):201-6. URL: http:// www.scopus.com/inward/record.url?eid=2-s2.0-85016396147\&partnerID $=$ MN8TOARS.

2. Ivashchenko DM. Kompleksne likuvannia hniinykh ran miakykh tkanyn u khvorykh z alerhiieiu do antybiotykiv. $\mathrm{PhD}$ [dissertation]. Kyiv:NMAPO;2017. 176 p. [In Ukrainian].

3. Dihtiar II. Prohnozuvannia uskladnen zahoiennia hniinykh ran u khvorykh pokhyloho ta starechoho viku. Visnyk Ukrainskoi medychnoi stomatolohichnoi akademii. Aktualni problemy suchasnoi medytsyny. 2009 Kvit 9;1(25):262-8. [In Ukrainian].

4. Krasnov OH, Khimich SD, Liakhovskyi VI. Renthenolohichni kryterii prohnozuvannia tiazhkosti perebihu syndromu diabetychnoi stopy druk. Klinichna khirurhiia. 2013 Lyst; 11(851) (Dodatok):16. [In Ukrainian].

5. Ligonenko OV, Borysenko MM, Digtyar II, Ivashchenko DM, Zubakha AB, Chorna IA, et al. Prohnozuvannia infektsiinykh uskladnen vohnepalnykh ran miakykh tkanyn. Klinichna khirurhiia. 2015 Hrud; 12(881):513. [In Ukrainian] URL: http://www.scopus.com/inward/record.url?eid=2s2.0-84965190344\&partnerID=MN8TOARS.

6. Malik SV, Osipov OS, Dihtyiar II, Lavrenko DO, Bezruchko MV. Prohnozuvannia rozvytku pisliaoperatsiinykh ranovykh uskladnen u khvorykh iz suputnim ozhyrinniam. Visnyk Ukrainskoi medychnoi stomatolohichnoi akademii. Aktualni problemy suchasnoi medytsyny. 2012 Lyst 12;3(39):150-5. [In Ukrainian].

7. Sheiko VD, Ohanezian AH. Prohnozuvannia infikuvannia obmezhenykh skupchen ridyny za tiazhkoho hostroho pankreatytu. Klinichna khirurhiia. 2015 Lypen; 7(875):30-1. [In Ukrainian]. 